\title{
FROM THE INTEGRATED SURVEY OF HISTORIC SETTLEMENTS TO THE PATTERN BOOK WITHIN THE BIM
}

\author{
F. Bianconi ${ }^{1}$, M. Filippucci ${ }^{1}$, G. Amoruso ${ }^{2}$, M. Bertinelli ${ }^{1, *}$ \\ ${ }^{1}$ Università degli Studi di Perugia, Perugia, Italy (fabio.bianconi, marco.filippucci)@unipg.it, mattia.bertinelli.eu@gmail.com \\ ${ }^{2}$ Politecnico di Milano, via Durando 38/A, Milano, Italy- giuseppe.amoruso@polimi.it
}

\section{Commission II}

KEY WORDS: HBIM, Digital Heritage Documentation, Laser Scanning, Photogrammetry, Heritage Management, Procedural Modelling, Pattern book

\begin{abstract}
:
The object of the study is the survey of minor historic settlements through integrated architectural survey techniques, the BIM modelling for the management of information at multiple levels, and the definition of pattern books to describe the qualities of the place. The research on cultural heritage representation made in Umbria, taking as a case study the historic hamlet of Lizori, a settlement located over the hill between Foligno and Spoleto in the town of Campello sul Clitunno (PG). It was selected as a paradigm of minor village and an experimental model to provide useful reference to reconstruct strategies, which is so important in the area recently affected by seismic events. The purpose of the research is therefore focused on finding a modus operandi in the management of multiple and uneven information. The goal is then to create a digital informative model functional to the conservation and restoration process and a knowledge-based reference for further study.
\end{abstract}

\section{INTRODUCTION}

\subsection{Overview}

The research examines the possibility of building processes of harvest and data management inside the historical and environment BIM, applied in a typical settlement in the central of Italy, the case study of Lizori at Campello sul Clitunno. The study shows the integration of urban and architectural survey technique, aimed to a digital management of data. Starting from a direct approach developed during an international Summer School promoted by Intbau Italia and the University of Perugia, the digital model of the place is the results of photogrammetry, Terrestrial Laser Scanning and a pre-Processing Laser and Image Data. The data produced and later processed according to the HBIM approach, projected the virtual model, introduced the LOD, LOG and LOI definitions, modelled process and opened to the As-Built BIM and the quality control for As-Built BIM. This path aimed to define a BIM Pattern Book, a new approach to the quality of a place assessment starting from digital data acquisition.

\subsection{The research questions}

The relief of an historic village is one of the most complex themes in the field of managing the cultural heritage, for it integrates multiple dimensional scales and for the stratification of those signs that sophisticate its form, and because it is addressed to the quality of urban space and landscape, overcoming the material characteristic. The problem of acquiring, managing and using the data is an essential issue for the valorization of the cultural heritage.

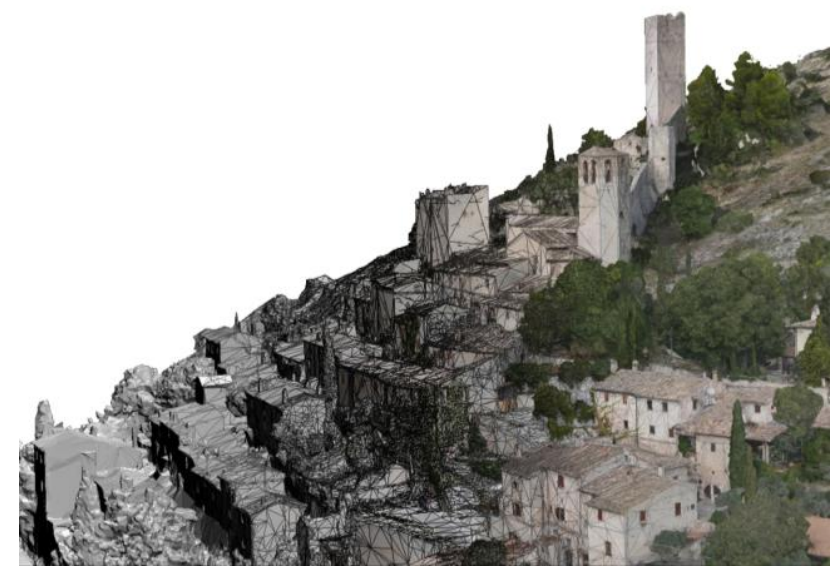

Figure 1. Virtual model of Lizori hamlet

Firstly is important to highlight the implicit statuary revision of the urban (Coppo, Boido, 2010) and architectonic relief (Docci, 2014), which is found on the dual and conflictual selection condition through the sign of determinate information according to the investigation needs (de Rubertis, 1994) and to the need of objectivity. It is an open system (Cundari, 2012), "irreplaceable instrument for the research and knowledge" (Docci, Maestri, 2006). The new digital revolution correlated to a different form of structuring the information in the model (Apollonio, Gaiani, Sun, 2012; Bryan, Bedford, Blake, 2009; Dellepiane, Niccolucci, 2011; Ioannides et al., 2012) and the inherent Building Information Model logic (Eastman, 2011), supports this internal dyscrasia also in the difficult applicative field of cultural heritage.

\footnotetext{
* Corresponding author
} 
To relief it means to know when it is possible to interpret the data through representation (Bianconi, Filippucci, Catalucci, 2017), while the H-BIM logics declines the theme of an open cataloguing of the information (Bianconi, 2005). H-BIM opens multiples questions (Biagini et alii, 2016; Arayici et alii, 2016; Murphy, McGovern, Pavia, 2009; Dore, Murphy, 2012), that in the present case study regarded the transferring of the cloud of points form the BIM system (Baik, 2017; Barazzetti et alii, 2015; Hichri et alii, 2013; Macher, Landes, Grussenmeyer, 2017; Tommasi, Achille, Fassi, 2016; Wang, Yong., Kim, 2015) to comprehend the integration (Guarnieri, Remondino, Vettore, 2006; Remondino, El-Hakim, 2006; Bonczak, Kontokosta, 2019) and the management of the information according to structured standards (Pavan, 2017). Data managing is tight to images production (Cundari, 1992), which compared to computational efficiency (Filippucci, Bianconi, Andreani, 2018; Bianconi et al., 2017a; Filippucci, 2010), it presents a structural problem on knowledge and on the parametrization of the realizing techniques, which are connoted by stratifications that hide their structural features.

The relief appears as a reconstruction of the ideal, a representation of the real that looks on the reconstruction of the original project (and not of the form) based on a functional vision of the "scale models" as Alberti sees it (Alberti, 1443). In this realization between virtual and model, the acting digital revolution is bringing out important transformations that overwhelm the study and the valorization of cultural heritage.

Historical hamlets are fundamental places for the heritage and the traditional value, especially those minor abandoned settlements (Bassanelli, 2009; Coletta, 1998), because they represent the practical synthesis of a slow adaption to the place using the local resources available. The material evidence of the hamlets, their images and visual impression, cannot be separated from the intangible component considering the material part as the result of the combination of thoughts, practices, rites and sociality, which all benefit from the natural component of the settlement place.

The theme is then tight to the investigation on the city image (Lynch, 1960), intended as the quality of urban landscape (Cullen, 1961), tight to the vision (Gregory, 1966), to its language (Kepes, 1944; Arnheim, 1954), to its meanings (Jencks, Baird, 1969), and to the place qualities (NorbergSchulz, 1980). Figurative centrality (Filippucci, 2012), the organic growth of the architectonic space (Filippucci, 2013) that becomes landscape (Bianconi, Filippucci, 2018) but also environment (Ahern, Cilliers, Niemela, 2014; Fu, Wangm, Schock, Stuckert, 2012; Meerow, Newell, Stults, 2016), determine a quality that overcomes the form. This is inherent immaterial relations and space balancing, because as Edith Stein said, in urban landscape "visible qualities motivates in us intentions" (Stein, 2003, p.191).

The aesthetic intention of urban space becomes then a linguistic issue (Choay, 1986), its ability in creating culture, it wants to discover and communicate its identity. In this contest the image "re-veals" the sense of place, it manifests it and at the same time, it hides it, because in an implicit way an identity language that needs to be codified, it preserves the narration of its history. This issue can become a theme also in digital, in the H-BIM approach, when the data correlate to information that are related to emerge the same relations that substantiate the spatial qualities. The challenge, still at the beginning, is tight to the same aim inherent the Anglo-Saxon approach of the pattern book. The descriptive characters of urban landscape gathered through graphic synthetic instruments organized as typological graphic abacus, for the definition of a graphic vocabulary and of appropriate glossaries, gathered in an analysis document named
Codice Tipologico o Pattern Book (Amoruso, Tarchini, 2004). To this representation per section, called "transects", are associated with a urban and extra-urban character, and they describe the changing of the territory image, while passing from the rural field to the urban field, describing the structural and characteristic elements of the differ portions of the territory (Duany, 2011).

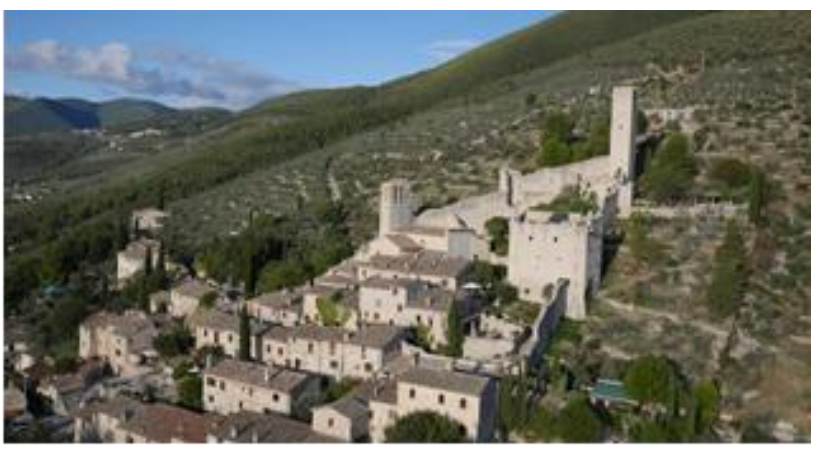

Figure 2. Aerial photo of the project site

The innovation proposed consists in filleting the phase of acquisition and interpretation of the data from the information modeling to build a repertoire of architectonic and urban models. It is a typological analysis document aimed to project and recovery an urban landscape, which presents reliefs, image illustrations, models and building designs, spaces and urban environment language and its chromatic and fitting characteristics. The document is preparatory for the writing of standards and graphic recommendations for the intervention in historical areas more that for the creation of new settlements (Amoruso, Mironenko, 2018).

Knowledge becomes then the base to rethink on the next landscape design, an instrument that opens to the participation and valorization of the place ant its potentialities (Bianconi, Filippucci, 2018a; Bianconi et alii, 2015; Bianconi et alii, 2017b; Bianconi, et alii, 2017c; Bianconi et alii, 2017d, Bianconi et alii, 2018b).

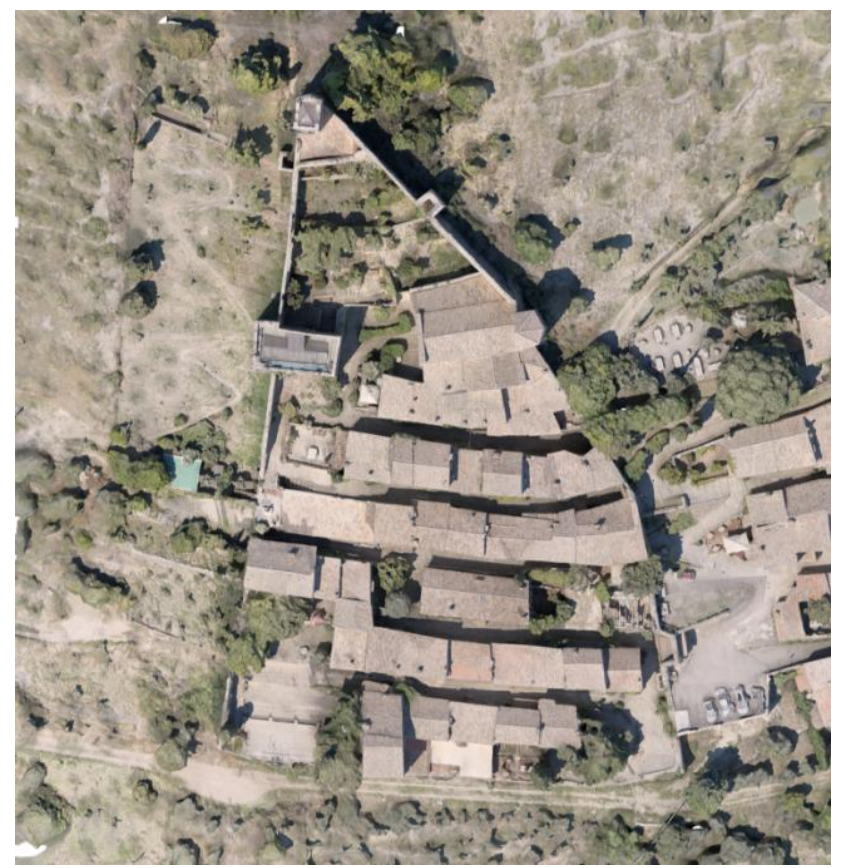

Figure 3. HD orthophoto obtained through photogrammetry 


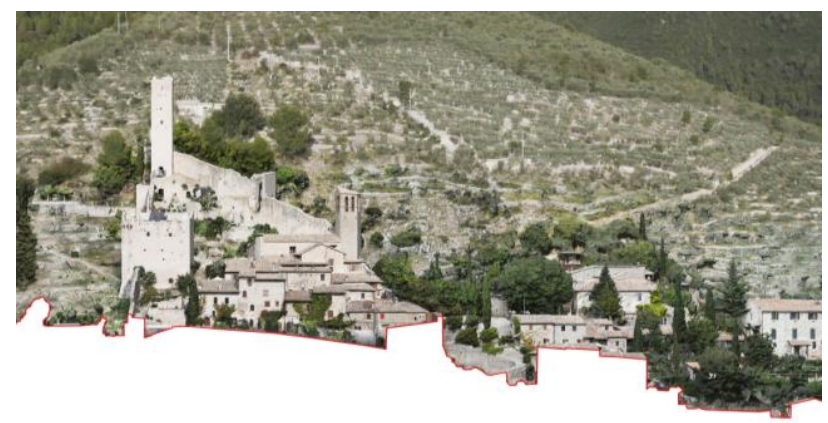

Figure 4. Environment section of the integrated model

\section{THE CASE STUDY OF LIZORI}

The research on cultural heritage representation carried out in Umbria taking as a case study the historic hamlet of Lizori, a settlement located over the hill between Foligno and Spoleto in the town of Campello sul Clitunno (PG). Selected as a paradigm of minor village in Umbrian landscape (Bianconi, 2016; Bianconi, Filippucci, 2010) and as an experimental model to provide useful indications for the reconstruction strategies, it so important in this area also recently afflicted by seismic events.

It is a triangular base castle (Quilici Gigli, 2012), clearly delimited in the late Middle Ages and virtually aligned up the temple of Clitunno (Emerick 1998; Nessi, 2012; Ulianich, 2014; Binazzi, 2015), a UNESCO World Heritage Site, positioned in control of the ancient Via Flaminia (Guerrini, 2000; Messineo, Carbonara. 1993).

The urban layout is quite characteristic, with a compact building pattern of a terraced arrangement of buildings with parallel plot lines and a trend that is set on the level curves that rapidly degrade along the slope. Its triangular shape has the vertex upstream, with the towers originally arranged on the corners and on the two sloping sides in an intermediate position. The village is in a state of perfect conservation, a well-kept place where architectural forms are in relation with nature as well as in the purely artistic decorative elements (Ragni, Sigismondi, 2010).

The project starts from an initial phase of urban survey of the settlement. The planning activity starts from an agreement between the municipal administrations, the University of Perugia and Meneghetti Foundation (Filippucci et alii, 2017) which better represent the community that brought the village gradually back to life, having been a pile of rubble for several years until the seventies abandoned.

\section{LABORATORIO SUL CULTURAL LANDSCAPE AND HERITAGE SKILLS}

The workshop aimed to document the material culture in Lizori's landscape and the transmission of memory. Through a technical and scientific formation on the heritage, the study wanted to share good practices and to propose operational references for the Italian Centre Field, which is interested in reconstruction after the seismic events.

The activities regarded the practice of the urban relief, with new technologies and the study of the local landscape system and of its building techniques, through the graphic manual expression and the digital design. The relief result presented methodologies integrated with documentation and representation of urban historical landscapes, according to UNESCO, and a treatment on the integrated environmental analysis techniques, applying those methodologies to Lizori case study.
The urban historical landscape is the material representation of regional cultures and traditions, which evolved in a relation with geographic and weather conditions of the territory, and with the availability of local resources and materials. A habitat matured over the centuries, full of history, heritage, social meanings, artisanship and traditions. Considered also as cultural landscape (Salerno, 2017), as a material expression of adaptation models to the different sites and of environmental resiliency, in where every element is identified and documented; this landscape is graphically described as a multiple information level catalogue, by developing appropriate semantic models (Amoruso, 2017). The direct analysis, the digital technologies and transcription methods offer instruments for the innovation of the knowledge and conservation process of this heritage, already applied in many international contests.

\section{TECHNIQUES OF SURVEY}

As preliminary survey, a model was developed through aerialphoto modeling techniques, a technique that offers considerable advantages for dense patterns, such as the case study. It was possible to survey the whole village, and represent the roof shape in detail using a professional EVO 4HSE drone. The flaying and the image acquisition phase lasted 8 hours. In this phase more than 20 marker were positioned on the ground to facilitate the aero-triangulation and to limit the cameras orientation error. The camera used for this phase is a LUMIX DMC-GH4 digital mirrorless with a single lens, on a Panasonic $14-18 \mathrm{~mm}$ optic. The software used for photo modelling is ContextCapture (Bentley). This software offers many advantages as the possibility of processing the project area in parts, according to the computer calculation power. Moreover, it can create clouds of points of a remarkable precision.

Once concluded the input and marker georeferencing phase, it is possible to move to the aero-triangulation phase, where among the options it is possible to set: density of key points, choice of methods of similar photos and adjustments of focal distortions. When completed the cameras alignment phase, it was the time to produce the dense cloud choosing points' density, texture quality and the mesh parameters. The relief counts then more than 6 million points, fruit of a process lasted 8 days.

However, some gaps coming from the density of the urban patter, the presence of narrow streets and the site morphology characterized the point cloud created by photo modelling.

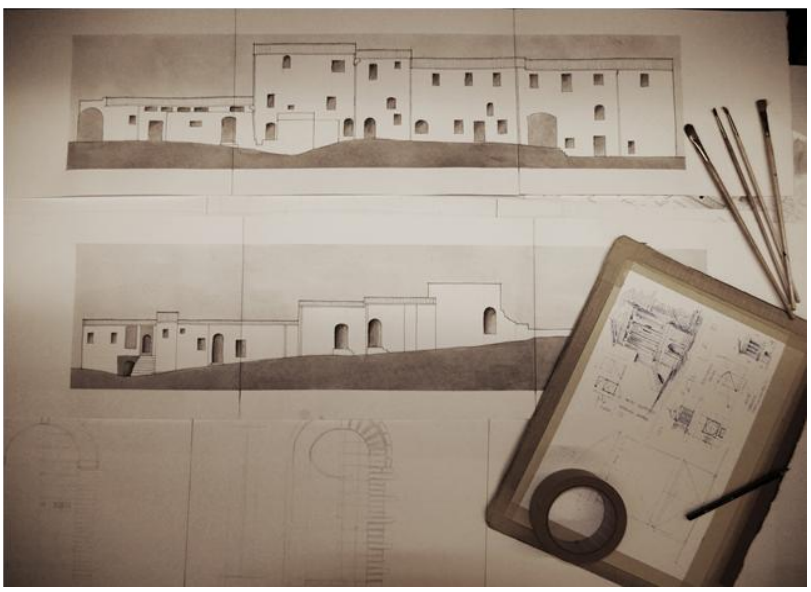

Figure 5. Risultati del rilievo diretto durante la Summer School INTBAU 

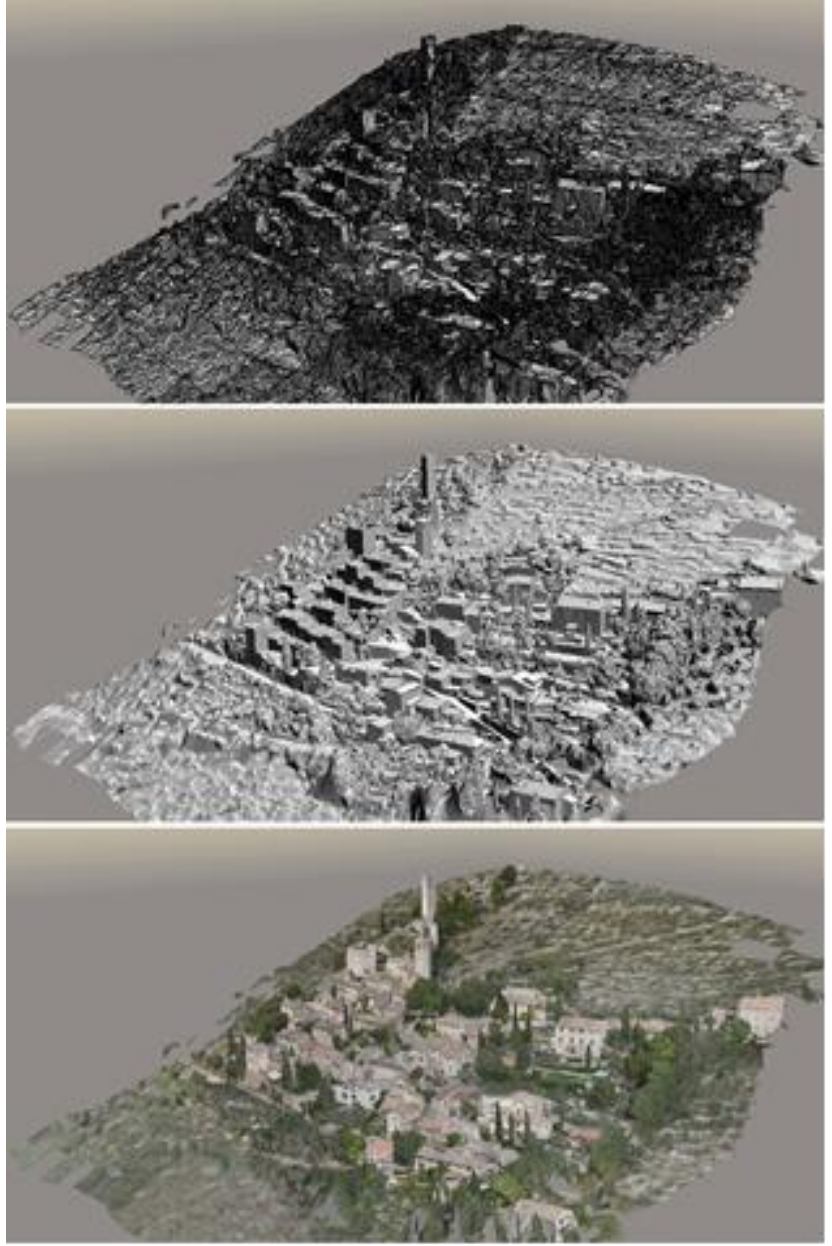

Figure 6. Texturized Mesh obtained through Context Capture

To create more data from a different point of view and with different detail, a laser scanner (Faro Imager 5010) within the survey workflow and the summer school integrated the workshop for data alignment and processing. Along the streets of the village with this instrument, the Faro Scene software carried out, oriented and aligned 20 scans. Each scan contains from 20 to 30 million points coloured through the camera integrating the scanner.

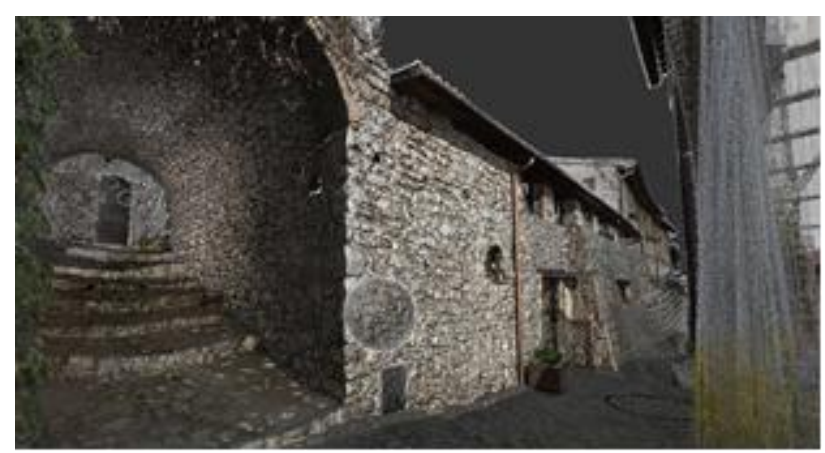

Figure 7. Recap view of the hamlet scan

Subsequently, the survey data were merged and geo-oriented through the 3Dreshaper software, thanks to which it was possible to extrapolate further data such as the land digital model and the built environment shape to hierarchize the point cloud.
The difficulty in this step is in georeferencing the two clouds created by two different procedures. Elaborated with GPS systems calibrated in an autonomous way, during the connection phase of the two clouds one cloud was chosen to be the reference one, in this case the one created by TLS, and the other cloud is subordinated, the one elaborated through photomodelling. At this point by triangulating homologue points, the program allows to rotate and climb the subordinated cloud, orienting in this way the two clouds and setting them in a homologue reference System.
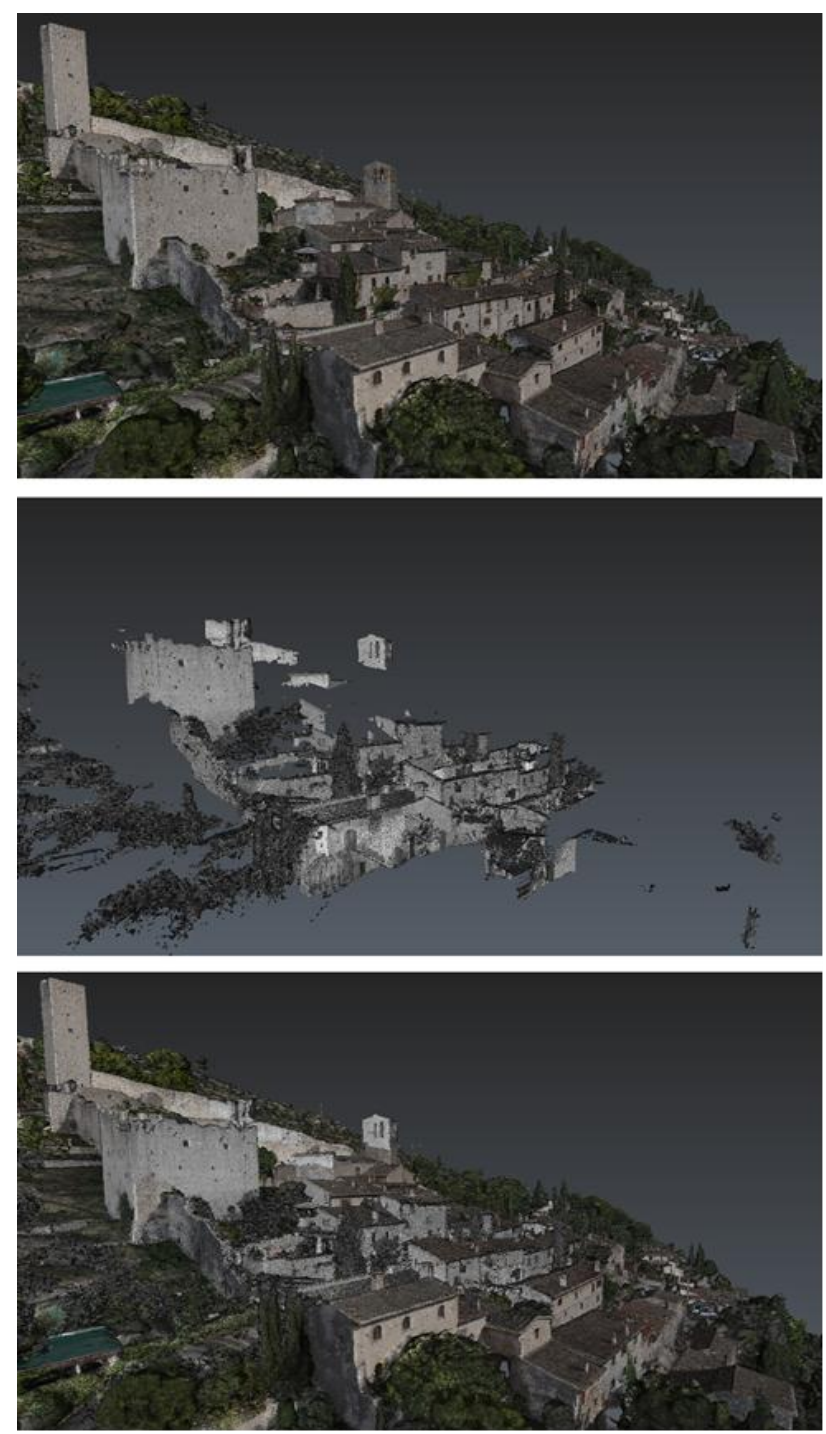

Figure 8. Connection of the clouds of points through 3dReshaper

\section{BIM E HBIM}

The research objective is the management of multiple information, which can guarantee a dynamic reading according to the levels of accuracy required. Complying with the ongoing renewal processes that incorporate a transformation of asset management, the analysis of the topic within H-BIM strategies is full interest.

By selecting the most widely used Autodesk BIM Revit software as a reference tool, operationally it was necessary to index the geo-referred data through the Recap software to ensure direct management in the identified digital environment. 
From the cloud of points is possible to move on to the interpretation of the shapes detected through the modelling of geometries. This are differently detailed in terms of scalar levels of detail, addressing the multiple issues related to the definition in parametric informational environment of singular and peculiar elements, such as those met in historical contexts like the case study.

The heart of the research is in the definition of data integration and information that correlates to the indexing and hierarchy of data that dynamically grow over time. The research led to the creation of an informative digital model developed on 5 levels of development (LOD), a concept derived by the American legislation and related to the case study. Level 0 is characterized by minimum LOG (Level of Geometry) and LOI (Level of Information), both gradually increase to the As-Built BIM, the LOG and LOI maxima. Using Revit to nest in a single file all the different levels, thus creating a "master" file from which it is possible to access to the levels where it is going to increase. This system allows us to contain all information within a single link and manage it in the hierarchy of their properties.

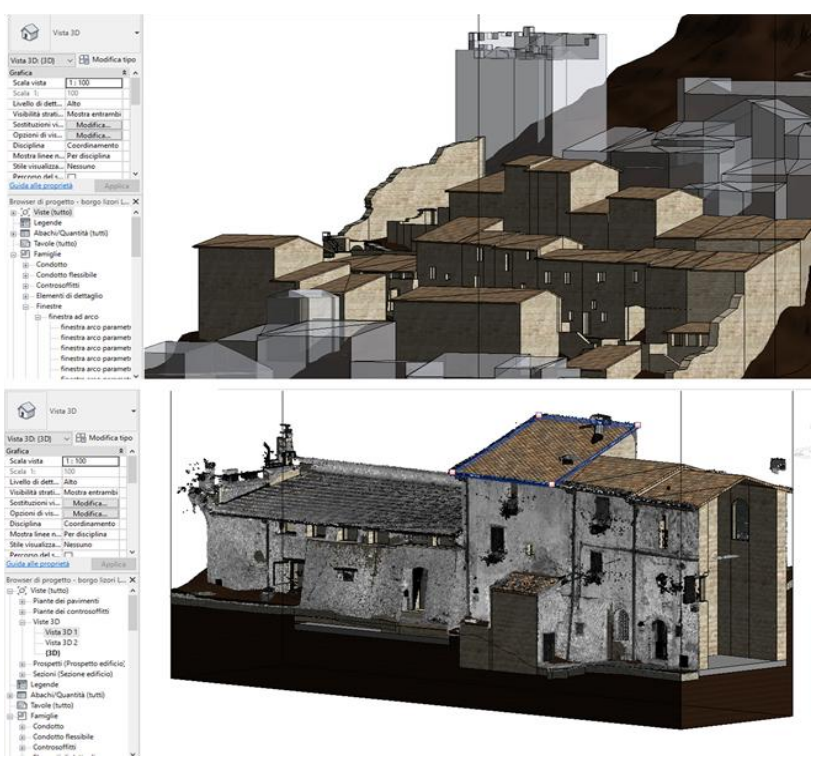

Figure 9. Revit, different LOD levels of the BIM model

The representation looks forward to the As-Built Bim, also called As-is, defined as the virtual place of all the elements that take in part in defying the cultural heritage knowledge. In this virtual environment, there are archive documents regarding the different relief sends, for the identification of the state of conservation and of degradation, for the identification of different phases and stratifications that interested the work over time, and all future document that may be produced. Actually, the case study presents all the problems regarding historical heritages, as the rare possibility of gathering information, their fragmentation, the doubtful reliability of all data, incomplete information, and the representation of unique constructive elements difficult to parametrize in BIM environments for their own nature or for their deterioration. It is then very difficult to reach out a LOD last grade for the all hamlet, even if, in the case study is developed a detailed representation of a single building, which was recently rebuilt and for this full of details data.

The As-Built BIM allows then to verify the geometric congruency between the real and the virtual model (Garagnani, Manferdini, 2013). Using 3DReshaper software, it was possible to export the BIM Revit model in FBX format and overlap it to the cloud of points from the laser scan, to calculate the variance, intended as the distance between homologue points of the BIM model and the relief. The obtained mistake is the sum of different factors and the average values are in the order of $5 \mathrm{~cm}$, an acceptable value connected to the vernacular character of urban space and the possible needs of a representative approximation.

\section{PATTERN BOOK BIM}

Finally, data management allows a query of the mutual relations that characterize urban space, with the aim of defining those characteristic patterns. The Pattern Book, developed mainly in the Anglo-Saxon field, proposed as a resource that derives from the identification of the local character, which wants to be strengthened. This approach, corresponding to the hierarchy of information, develops on several levels of detail starting from a broad urban scale up to a level where constructive systems and individual details are considered. The management of information can then be crossed in the definition of a digital spatial catalogue capable of identifying the multiple typological and constructive solutions, but of comparing immaterial relations that define the quality of the places, such as vision, the distances between buildings, the volumetric balance, the rhythm of urban pattern. In this way, it is possible to define a workflow able to show relations, according to a replicable approach based on the different entered data.

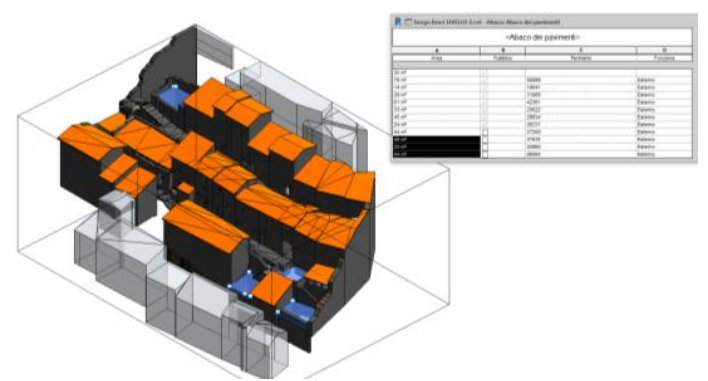

Figure 10. External private and public spaces as the example of the Pattern Book

Through the creation of parameters is possible to characterize in a semantic way the model, in order to find here characteristic parameters of the place. Between the different values, is described the abacus that shows the external flooring, public and private, and their space relation, in quantity and quality. This description characterizes one of the relations useful to support project choices on urban and landscape development of the hamlet on this theme. Considering the interactions between spaces, and not only the single work itself.

\section{CONCLUSION}

The presented procedure wants to apply a knowledge- and evidence-based approach, which establishes itself on the deepen knowledge on the site conditions (and of its evolution and conformation over historical and natural events).

The strategies proposes to include, in the decisional processes, information modelling and to address visualization instruments to use pattern books, graphic project codes and environmental simulations. Knowledge technologies are integrated to produce an advanced approach, economically advantageous for territorial and morphological data modelling, for the semantic representation and for the documentation on the historical urban settlement. 


\section{ACKNOWLEDGEMENTS}

The authors thanks the Foundation for the Science Research Antonio Meneghetti for the support given to the performed activities and thanks to Studio Fotografico Sannipoli and to RELEVO to the support in the architectural survey.

\section{REFERENCES}

Ahern J., Cilliers S., Niemela J., 2014. The concept of ecosystem services in adaptive urban planning and design: A frame work for supporting innovation, Landscape and Urban Planning, $125, \quad$ pp. 254-259, http://dx.doi.org/10.1016/j.landurbplan.2014.01.020.

Akca, D., Remondino, F., Novak, D., Hanusch, T., Schrotter, G., Grün, A., 2006. Recording and modeling of cultural heritage objects with coded structured light projection systems. In 2nd International Conference on Remote Sensing in Archaeology. Institute of Geodesy and Photogrammetry, ETH Zurich, 2006. p. $375-382$.

Alberti, L.B., 1443. De re aedificatoria. Firenze.

Amoruso, G., 2017 Developing semantic models for the Historic Urban Landscape regeneration. In: Amoruso, G. (ed) Putting Tradition into Practice: Heritage, Place and Design, Springer International Publishing AG, Cham, pp. 769-777

Amoruso, G., Mironenko P., 2018. Ricostruire la bellezza. La rappresentazione per il paesaggio urbano storico, Lampi di Stampa, Milano.

Amoruso, G., Tarchini, M. L., 2004. La proyectación de la calidad urbana: un código gráfico digital para la representación y el recupero de la ciudad histórica. In: IX Seminario Internacional Forum UNESCO - Universidad y Patrimonio, Buenos Aires.

Apollonio, F.I., Gaiani, M., Sun, Z., 2012. BIM-based Modeling and Data Enrichment of Classical Architectural Buildings. SCIRES-IT - SCIentific RESearch and Information Technology, 2(2), 41-62. doi.org/10.2423/I22394303V2N2P41

Arayici Y., Counsell J., Mahdjoubi L., Nagy G.A., Hawas S., Dweidar K., 2017. Heritage Building Information Modelling, Routledge, London.

Arnheim, R., 1954. Art and Visual Perception. A Psychology of the Creative Eye, University of California Press, Berkeley.

Baik, A., 2017. From point cloud to Jeddah Heritage BIM Nasif Historical House - case study. Digital Applications in Archaeology and Cultural Heritage, 4, pp. 1-18.

Barazzetti, L., Banfi, F., Brumana, R. and Previtali, M., 2015. Creation of Parametric BIM Objects from Point Clouds Using Nurbs. The Photogrammetric Record, 30, 152:, pp.339-362.

Bonczak B., Kontokosta, C.E., 2019. Large-scale parameterization of $3 \mathrm{D}$ building morphology in complex urban landscapes using aerial LiDAR and city administrative data. Computers, Environment and Urban Systems, 73, pp. 126-142.
Bassanelli, M. 2009. Geografie dell'abbandono - La dismissione dei borghi d'Italia. DPA - Politecnico di Milano, Milano.

Biagini, C., Capone, P., Donato, V., Facchini, N., 2016. Towards the BIM implementation for historical building restoration sites. Automation in Construction, 71, 1, 74-86.

Bianconi F., 2005. Segni Digitali, Morlacchi, Perugia.

Bianconi F., Filippucci M. (eds.), 2018a. 1 prossimo paesaggio. Realtà Rappresentazione Progetto. Gangemi Editore, Roma.

Bianconi, F., Filippucci, M., Catalucci, S., 2017b. Line and points. Critical analysis of evolution of archaeological survey in forty years of experiences in Umbria. DISEGNARE CON, 10(19), 4-1-E4.20.

Bianconi, F., Filippucci, M., 2018b. Il disegno del prossimo paesaggio. In Bianconi F., Filippucci M. (eds.), Il prossimo paesaggio. Realtà, rappresentazione, progetto, Gangemi, Roma, pp. 26-27.

Bianconi, F., 2016. La costruzione del paesaggio umbro, in A. Berrino, A. Buccaro (Eds.), Delli Aspetti de Paesi. Vecchi e nuovi Media per l'Immagine del Paesaggio. CIRICE - Centro Interdipartimentale di Ricerca sull'Iconografia della Città Europea, Napoli.

Bianconi, F., Catalucci, S., Filippucci, M., Marsili, R., Moretti, M., Rossi, G., Speranzini, E., 2017a. Comparison between two non-contact techniques for art digitalization. In Journal of Physics: Conference Series, Vol. 882, No. 1, p. 012005 https://doi.org/10.1088/1742-6596/882/1/012005

Bianconi, F., Clemente, M., Filippucci, M., Salvati, L. (2018). Re-sewing the urban periphery. A green strategy for fontivegge district in Perugia. TeMA Journal of Land Use, Mobility and Environment, 11(2018), 107-118.

Bianconi, F., Filippucci, M., 2010. Lavoro e paesaggio. Catalogazione e analisi dei beni rurali di Castiglione del Lago (PG)., in C. Gambardella (Ed.), Le vie dei Mercanti. Med Townscape anb Heritage: Knowledge Factory. (Vol. 1, pp. 417424). Napoli: La scuola di Pitagora.

Bianconi, F., Filippucci, M., Andreani, S, (2015), Città smart e contratti di paesaggio, in "Istituzioni del Federalismo" 1(4), pp. 895-926.

Bianconi, F., Filippucci, M., Andreani, S., 2017c. La partecipazione per la riconnessione fra campagna e città. Il ridisegno delle relazioni attraverso il contratto di paesaggio e la strategia territoriale del cibo. In G. F. Ferrari (Ed.), La prossima città. Mimesis, Milano.

Bianconi, F., Filippucci, M., Ciarapica, A., 2017b. Landscape, territories, knowledge. From umbrian region's Atlas of Objectives to lake Trasimeno Landscape Contract. In M. Clemente, R. Biasi, Salvati L. (eds.), Crisis Landscape. Opportunities and weaknesses for a sustainable development Franco Angeli, Milano, pp. 87-110. 
Bianconi, F., Filippucci, M., Clemente, M., 2017a. Biodiversity protection and landscape evaluation: two proposals for Umbria Region in Europe 2020 strategy. In M. Clemente, R. Biasi, Salvati, L. (eds.), Crisis Landscape. Opportunities and weaknesses for a sustainable development Franco Angeli, Milano, pp. 111-124.

Binazzi, G., 2015. Considerazioni sulla cronologia del Tempietto sul Clitunno. LANX. Rivista della Scuola di Specializzazione in Archeologia-Università degli Studi di Milano, 18, pp. 1-47.

Bryan, P., Bedford, J., Blake, B., 2009. Metric Survey Specifications for Cultural Heritage., D. Andrews, (ed.). English Heritage, Swindon.

Choay, F., 1986. Urbanism and semiology. In The city and the sign: An introduction to urban semiotics, pp. 160-175.

Coletta, T., 1998. Il paesaggio dei centri abbandonati. TRIA - Il paesaggio nella storia nella cultura nell' arte e nella progettazione urbanistica assunti teorici ed esperienze, 2, pp. $117-125$

Coppo D., Boido C., 2010. Rilievo urbano. Conoscenza e rappresentazione della città consolidata. Alinea, Firenze.

Cullen, G., 1961. Townscape. Urban landscape. Morphology and design. Architectural Press, London.

Cundari, C., 1992. L'immagine nel rilievo. Atti del Seminario di Studio. Lerici, 10 - 11 maggio 1988. Roma, 20 - 22 febbraio 1989. Gangemi, Roma.

Cundari, C., 2012. Il Rilievo architettonico. Ragioni. Fondamenti. Applicazioni. Aracne, Roma.

de Rubertis, R., 1991. La relazione introduttiva. Dimensioni del disegno. Il rilievo fra Storia e Scienza. $X Y, 11-12$.

de Rubertis, R., 1994. Il disegno dell'architettura. NIS, Roma.

Dellepiane, M., Niccolucci, F., 2011. VAST 2011. Proc of the 12th International Con-ference on Virtual Reality, Archaeology and Cultural Heritage. Switzer-land: Euro Graphics Association Aireola-Ville, pp. 51-61.

Di Giuda G.M., Re Cecconi F., Maltese S., Villa V., 2017. Il BIM per la gestione dei patrimoni immobiliari - Linee guida, livelli di dettaglio informative grafico (LOD) e alfanumerico (LOI). Hoepli, Milano.

Docci, M., Maestri, D., 2006. Manuale di rilevamento architettonico e urbano (8th ed.). Laterza, Roma.

Dore C., Murphy M., 2012. Integration of Historic Building Information Modeling (HBIM) and 3D GIS for recording and managing cultural heritage sites. In Virtual Systems and Multimedia (VSMM), 18th International Conference on. IEEE, 2012. p. 369-376.
Duany, A. 2011. Garden Cities: Theory \& Practice of Agrarian Urbanism. The Prince's Foundation for the Built Environment, London.

Eastman, C. M., 2011. BIM handbook: a guide to building information modeling for owners, managers, designers, engineers and contractors. John Wiley \& Sons, Hoboken.

Emerick J., 1998 The Tempietto del Clitunno near Spoleto, Pennsylvania State University Press, Harrisburg.

F. Giovaneti, R. Argaglia, G. Boni, E. Bruschi, G. Cangi, A. Giuffrè, A. Orsini, 1992. Manuale del Recupero di Città di Castello. Tipografia del genio civile, Roma.

Filippucci M., 2012. Dalla forma urbana allimmagine della città. Percezione e figurazione all'origine dello spazio costruito, tesi di Dottorato, Sapienza Università di Roma, Dottorato in Scienze della Rappresentazione e del rilievo, XXIV ciclo, in hdl.handle.net/10805/1506.

Filippucci, M, Bianconi, F, Bettollini, E, Meschini, M, Seccaroni, M, 2017. Survey and Representation for Rural Landscape. New Tools for New Strategies: The Example of Campello Sul Clitunno, in Proceedings 2017. International and Interdisciplinary Conference IMMAGINI? Image and Imagination between Representation, Communication, Education and Psychology. Bressanone: MDPI.

Filippucci, M., 2010. Nuvole di pixel. La fotomodellazione con software liberi per il rilievo d'architettura. DISEGNARE CON..., 3, pp. 50-63. https://doi.org/10.6092/issn.1828$5961 / 2081$

Filippucci, M., 2013. Disegno e figurazione, scrittura e oralità. L'immagine della città e il valore della percezione per la ricerca delle scienze della rappresentazione in Carlevalis L. (ed.), Linee di Ricerca nell'area del Disegno Approfondimenti dalle tesi di dottorato, Aracne, Roma.

Filippucci, M., Bianconi, F., Andreani, S., 2018. Computational Design and Built Environments. In 3D printing: breakthroughs in research and practice. IGI Global, Hershey, pp. 361-395. https://doi.org/10.4018/978-1-5225-1677-4.ch019

Fu X., Wangm X., Schock C., Stuckert, T., 2016. Ecological wisdom as benchmark in planning and design. Landscape and Urban Planning, 155, pp. 79-90. http://dx.doi.org/10.1016/j.landurbplan.2016.06.012.

Garagnani, S., Manferdini A. M., 2013. Parametric accuracy: Building Information Modeling process applied to the cultural heritage preservation. International Archives of the Photogrammetry, Remote Sensing and Spatial Information Sciences, 2013, 5.1.

Gregory R.L., 1966. Eye and Brain: The Psychology of Seeing, Weidenfeld and Nicolson, London.

Guarnieri, A., Remondino, F., Vettore, A., 2004. Photogrammetry and round - based laser scanner: Assessment of metric accuracy of the 3D model of Pozzoveggiani Church. Videometrics VIII. International Society for Optics and Photonics, p. 56650M. 
Guerrini, G., 1995. Le Fonti del Clitunno: Campello sul Clitunno. Quattroemme, Ponte San Giovanni.

Hichri, N., Stefani, C., De Luca, L., Veron, P., Hamon, G., 2013. From point cloud to BIM: a survey of existing approaches. XXIV International CIPA Symposium, Strasbourg, France.

Ioannides, M., Fritsch, D., Leissner, J., Davies, R., Remondino, F., Caffo, R., 2012. Progress in Cultural Heritage Preservation: 4th International Conference, EuroMed 2012, Lemessos, Cyprus, October 29--November 3, 2012, Proceedings. Springer Science \& Business Media, 2012.

Jencks, C., Baird, G., 1969. Meaning in architecture, The Cresset Press, London.

Kepes, G., 1944. Language of vision, Paul Theobald, Chicago.

Lynch, K., 1960. The image of the city, The technology Press and Harvard University Press, Cambridge.

Macher, H., Landes, T., Grussenmeyer, P., 2017. From Point Clouds to Building Information Models: 3D Semi-Automatic Reconstruction of Indoors of Existing Buildings, Applied Sciences, 7 (10), p.1030.

Meerow S., Newell J.P., Stults M., 2016. Deining urban resilience: A review. Landscape and Urban Planning, 147, pp. 38-49, http://dx.doi.org/10.1016/j.landurbplan.2015.11.011.

Messineo, G, Carbonara, A., 1993. Via Flaminia. Istituto poligrafico e Zecca dello Stato, Roma.

Murphy M., McGovern E., Pavia S., 2009. Historic building information modelling (HBIM). Emerald Group Publishing Limited, Bingley.

Nessi S., 2012. Il Tempietto del Clitunno tra paganesimo e cristianesimo. Accademia di Montefalco: Tipolitografia Nuova Eliografica, Montefalco.

Norberg-Schulz, C., 1980. Genius Loci: Towards a Phenomenology of Architecture. Academy Editions Ltd, New York.

Pavan A., Mirarchi C., Giani M., 2017. Progettare, costruire e gestire nell'era digitale. Tecniche Nuove, Milano.

Quilici L., Quilici Gigli, S., 2002. Citta dell'Umbria: L'Erma di Bretschneider, Roma.

Ragni, S., Sigismondi F., 2010. La chiesa della Madonna della Bianca a Campello sul Clitunno. Era Nuova, Perugia.

Remondino, F. and S. El-Hakim, 2006: Image-based 3D modeling: a review. The Photogrammetric Record, 21 (115).

Salerno, R., 2017 Enhancing Not-Outstanding Cultural Landscapes in a European Perspective: A Challenge for Digitization. In Amoruso G (ed), Putting Tradition into Practice: Heritage, Place and Design. Springer International Publishing AG, Cham, pp.3-8.
Stein, E., 2003. Potenza e atto. Studi per una filosofia dell'essere. Città Nuova, Roma.

Theiler, P. W. and Schindler, K., 2012. 'Automatic Registration of Terrestrial Laser Scanner Point Clouds using Natural Planar Surfaces'. ISPRS Annals of Photogrammetry, Remote Sensing and Spatial Information Sciences, 3, pp. 173-178.

Tommasi, C., Achille, C., and Fassi, F., 2016. From point cloud to Bim: a modelling challenge in the cultural heritage field, The International Archives of the Photogrammetry, Remote Sensing and Spatial Information Sciences, Volume XLI-B5, pp. 429436.

Ulianich, B. Le iscrizioni del tempietto del Clitunno: primi appunti. Accademia Fulginia, Foligno

Wang, C., Yong K.C., Kim C., 2015. Automatic BIM component extraction from point clouds of existing buildings for sustainability applications. Automation in Construction, 56, pp. 1-13.

Drone 4HSE - http://www.italdron.com/it/droni-professionali-eaccessori/droni-professionali/highone-4hse-pro-fotogrammetria

3DReshaper - https://www.3dreshaper.com/en/

Camera Drone: DMC-GH4 Fotocamera mirrorless digitale a obiettivo singolo https://www.panasonic.com/it/consumer/fotocamere-evideocamere/fotocamere-lumix-g/dmc-gh4eg-k.specs.html

ContextCapture Center

https://www.bentley.com/it/products/product-line/realitymodeling-software/contextcapture-center

Faro Imager 5010 - https://www.zf-laser.com/Z-F-IMAGER-R5010.3d_laserscanner0.0.html? \&L=1

Faro Scene - https://www.faro.com/it-it/prodotti/design-delprodotto/faro-scene/

Ottica camera: LUMIX G H-H014A https://www.panasonic.com/it/consumer/fotocamere-evideocamere/obiettivi/h-h014a.html

Recap Autodesk

https://www.autodesk.com/products/recap/overview

Revit $2019 \quad$ Autodesk

https://www.autodesk.it/products/revit/overview

Rilevazioni Laser scanner Relevo Italia - www.relevo.it Via dei bastai 2506132 Perugia 